\title{
GAYA BAHASA PEREMPUAN INDONESIA DALAM MEDIA BARU
}

\author{
Errika Dwi Setya Watie \\ (errika@ftik.usm.ac.id) \\ (Dosen Ilmu Komunikasi FTIK USM)
}

\begin{abstract}
Abstrak
Media is a means for someone to be able to convey information to others. Currently there are two classes of media. Old media / conventional and new media. Ideally, on the both media, the position and status of all users are the same media. But in reality, in this case, social media as part of the new media, it still occurs mute identity in social media for some women. Based on the observations, a style that used by women on her status in her social media account is still much that is likely to show a distinctive feminine style, which tends to give priority to the relationship, avoid disputes, and minimize the dominant impression.
\end{abstract}

\section{Kata Kunci : Perempuan, media baru, Gaya Bahasa}

\section{Pendahuluan}

Media adalah sarana bagi seseorang untuk bisa menyampaikan suatu informasi kepada orang lain. Saat ini ada dua penggolongan media. Old media/konvensional dan media baru/new media. Flew menyebutkan bahwa interaktifitas merupakan konsep sentral dalam memahami new media. (Flew, 2002: 21). Adanya interaktifitas yang tinggi dalam new media inilah yang membedakannya dari old media.

Idealnya, baik dalam old maupun new media, posisi dan kedudukan semua pengguna media tersebut adalah sama. Namun Cheris Kramarae dalam Griffin (2006) pada Muted group Theory mengungkapkan bahwa perempuan dan anggota dari kelompok subordinat lain, tidaklah diperlakukan secara sama

(Griffin, 2011: 498). Pemilihan kata yang menyudutkan perempuan masih sering ditemui, ruang "bicara" untuk wanita masih terasa terbatasi, wanita seolah masih dibisukan dalam old media. Secara umum, cara "bicara" perempuan dalam
"....Woman (and members of other subordinate groups) are not as free or as abel as men are to say what they wish, when and where they wish, because the words and the norms fir their use have been formulated by dominant group, men"

Pada media konvensional/old media, traditional power relation antara pria dan wanita tampak masih terjadi. Dalam media, apa yang ingin dikatakan perempuan tidak dapat diungkapkan secara benar-benar tepat karena bahasa yang ada bukanlah buatan mereka. Dan, layaknya seperti bahasa kedua, ketika translasi selesai dilakukan, kata-kata yang telah ditranslasikan itu tidak benar-benar mengungkapkan maksud perempua old medi masih sangat dibatasi dengan aturan patriarki yang selama ini berjalan. Perempuan yang bicara blak-blakan, apa adanya, keras masih ditempatkan pada posisi yang "tidak pantas". 
Kehadiran New Media dengan segala keunggulannya seharusnya membawa angin segar bagi perempuan. Dalam media

media sosial dalam perkembangan jaman internet 2.0, makin memperluas ruang bagi tiap orang, termasuk perempuan untuk mempresentasikan diri. Luik mengatakan, bahwa salah satu yang menarik dari media sosial adalah sesama pengguna akan memiliki konstruksi identitas masing-masing. (Luik, 2011:114). Sehingga bagaimana gaya bahasa perempuan dalam media baru menjadi menarik untuk dikaji, mengingat kebebasan dan keleluasaan yang diberikan new media pada para penggunanya. Pilihan kata yang digunakan para perempuan dalam pesan yang diciptakannya dalam media barupun lebih luas, tak jarang juga mereka tak lagi memikirkan apakah kata dan pendapat yang mereka postingkan di media baru sesuai dengan pemikiran perempuan di ranah tradisional.

\section{Tinjauan Pustaka}

Mendefinisikan kata komunikasi sebenarnya tidaklah semudah kelihatannya. Orang dengan masingmasing latar belakangnya, bisa mendefisikan kata komunikasi dengan cara yang berbeda. Dalam hal ini definisi dibutuhkan tentunya untuk membantu studi yang dilakukan. (Sobur, 2006 : 157) mengungkapkan bahwa Simbol dalam "bahasa" komunikasi adalah sesuatu yang digunakan untuk menunjukkan sesuatu yang lain, berdasarkan kesepakatan kelompok orang. Bahasa, kata, gesture, tanda, merupakan bagian dari symbol yang digunakan manusia dalam mendefinisikan sesuatu atau menyampaikan sesuatu ke orang lain. Sehingga bagaimana bahasa, kata, gesture, tanda digunakan manusia adalah apa yang dipelajari dalam ilmu komunikasi, termasuk juga bagaimana implikasi yang baru, perempuan bisa menampilkankan dirinya dengan lebih bebas. Hadirnya

muncul dari penggunaan berbagai symbol tersebut (Adler \& Rodman, 2006 : 4).

Fiske menekankan bahwa komunikasi saat ini tidak bisa lagi dipahami sebagai suatu proses namun komunikasi lebih merupakan pembangkitan makna (Fiske, 2007:59). Sehingga bisa dikatakan bahwa kesepahaman bersama akan suatu hal akan memunculkan pemaknaan dalam komunikasi yang terjalin. Perbedaan pemahaman tentunya akan membawa pada kesalahpahaman.

Jesse Delia dalam constructivism theorynya mengungkapkan bahwa tiap orang akan mengkonstruksi pesan yang diproduksinya sedemikian rupa sehingga akan bisa diterima orang lain dengan lebih baik, atau yang diistilahkan Delia dengan Person Centered Message (Griffin, 2011: 190-193). Lebih lanjut dijelaskan Delia bahwa produksi pesan oleh seseorang akan melalui Goal-Plans-Action Model yang diadopsinya dari Professor James Dillard (Griffin, 2011: 195-197). Goal, merupakan hal mendasar dalam produksi suatu pesan, karena dengan memiliki tujuan/goal, seseorang akan bisa merencanakan pesan dan bagaimana pesan tersebut akan disampaikan. Plans, merupakan perencanaan pesan yang dilakukan melalui procedural records yang dimiliki tiap orang. Procedural records adalah kumpulan memori seseorang tentang suatu tindakan beserta konsekuensinya. Actions, merupakan tahapan akhir dimana seseorang melaksanakan apa yang sudah direncanakannya, disinilah pesan tersebut telah selesai diproduksi dan disampaikan.

Palfrey dan Gasser menyebutkan bahwa perempuan yang hidup dalam era digital saat ini, sulit untuk benar-benar 
menyembunyikan identitasnya, karena perempuan dalam era digital akan lebih banyak berinteraksi dengan orang lain dibanding perempuan yang hidup di jaman dahulu. Sehingga akan ada semakin banyak orang yang mungkin mengkonfirmasi kebenaran identitas yang ditampilkannya (Palfrey dan Gasser, 2008: 17-24).

Flew dalam bukunya New Media : anintroduction menjelaskan bahwa new media merupakan media yang menawarkan digitisation, convergence, interactiviy, dan development of network terkait pembuatan pesan dan penyampaian pesannya. (Flew, 2002: 11-22). Kemampuanya menawarkan interaktifitas ini memungkinkan pengguna dari new media memiliki pilihan informasi apa yang dikonsumsi, sekaligus mengendalikan keluaran informasi yang dihasilkan serta melakukan pilihan-pilihan yang diinginkannya. Kemampuan menawarkan suatu interactivity inilah yang merupakan konsep sentral dari pemahaman tentang new media.

Rasmussen

(2000)

mengungkapkan bahwa media baru memiliki kontribusi pada integrasi sosial masyarakat. Media baru menjadi jembatan yang menghubungkan dua jarak besar dalam level komunikasi yaitu komunikasi pribadi dan komunikasi massa. Tidak seperti halnya yang terjadi pada media lama, media baru memegang peranan besar dalam hidup masyarakat saat ini, media baru mampu mengarahkan kehidupan individu seseorang, sekaligus menunjukkan berbagai cara penggunaan media dalam menyampaukan pesan, dan memungkinkan adanya lebih banyak orang terlibat didalamnya. Singkatnya media baru memungkinkan adanya keterlibatan aktif penggunanya, tidak seperti halnya yang terjadi di media lama (McQuail, 2010: 142).
Terkait dengan penggunaan media, semua orang pasti pernah menggunakan media, baik itu media konvensional/old media maupun media baru/new media. Namun demikian, Utari memaparkan bahwa perempuan menjadi obyek yang menarik dalam penelitian tentang media karena ada kondisi ketimpangan gender di ranah sosial, dimana perempuan seringkali menjadi pihak yang termarginalkan, tertindas oleh pihak yang lain (Utari, 2011:56).

Dalam beberapa teori gender dari kaum feminist disebutkan bahwa bagaimana perempuan berkomunikasi dan berekspresi dalam media dibatasi oleh aturan-aturan tertentu. Perempuan sulit untuk menjadi dirinya sendiri yang sebenar-benarnya di media. Perempuan sulit mengungkapkan pendapatnya dan berekspresi sebebas-bebasnya di media. Sandra Harding dan Julia T. Wood, melalui Standpoint Theory.nya mengungkapkan bahwa cara yang paling baik untuk menunjukkan bagaimana dunia berjalan adalah dengan memulainya dari standpoint perempuan dan kelompokkelompok lain yang terpinggirkan di masyarakat (Griffin, 2011:482). Dalam standpoint theory dikatakan bahwa budaya tidak dialami sama oleh semua anggota budaya tersebut. Budaya sebenarnya memiliki hirarki, sehingga kelompok berbeda didalamnya memiliki kekuatan, kesempatan, dan pengalaman yang berbeda pula.

\section{Cheris Kramarae melalui Muted Group} Theorynya (Griffin, 2011: 460) menyatakan bahwa bahasa pada dasarnya, adalah sebuah man-made construction. Kramarae menandaskan bahwa bahasa dari sebuah budaya khusus tidak melayani semua orang yang mengucapkannya secara sama, hal ini karena orang yang mengucapkannya tidak memiliki formulasi pemaknaan yang sama 
meskipun struktur yang dimiliki sama. Perempuan, dan anggota dari kelompok subordinat lain, tidaklah bebas atau bisa mengatakan apa, yang ingin mereka katakan, kapan, dan di mana, karena katakata dan norma-norma yang mereka gunakan telah diformulasikan oleh kelompok dominan, yaitu pria. Man-made language membantu mendefinisikan, menjatuhkan, dan meniadakan perempuan. Perempuan merupakan bagian dari the muted group atau kelompok yang dibungkam. Karena dominansi maskulin dalam komunikasi publik adalah sebuah realitas yang tengah terjadi, Untuk berpartisipasi dalam masyarakat, perempuan harus mentranslasikan model mereka ke dalam sistem ekspresi pria yang dipakai masyarakat selama ini.

Kramarae menandaskan bahwa walau memang internet bisa memfasilitasi interaksi antar perempuan lintas waktu dan ruang, namun apa yang muncul di internet masih saja seolah hanyalah forum dan taman bermain pria. Guna mendukung pemikirannya ini Kramarae menunjukkan empat metafora yang biasa digunakan untuk mendiskripsikan internet, yang memperlihatkan mengapa perempuan ternyata masih mengalami pembungkaman/ muted, dan janji akan kesamaan gender belum juga terpenuhi. Metafora ini penting, karena tiap metafora membentuk cara pikir baru. Empat metafora tentang internet yang dikemukakan Kramarae tersebut adalah The Information Highway, The New Frontier, Democracy, The Global Community (Griffin, 2011:498-499).

Judith Butler dalam bukunya Gender trouble menegaskan bahwa gender trouble sedang terjadi di masyarakat bahwa di masyarakat (Butler, 1999: vii-viii\&1-9). Mereka yang mengaku feminis seringkali justru melakukan kesalahan dengan mencoba untuk menegaskan bahwa 'perempuan' adalah kelompok dengan karakteristik dan kepentingan tertentu. Pada gilirannya ini justru menjadi blunder di kalangan feminis karena apa yang mereka ungkapkan justru menjadi semacam peraturan yang makin menegaskan perempuan harusnya seperti apa dan pria harusnya seperti apa. Butler menegaskan bahwa "gender is an identity tenuously constituted in time, instituted in an exterior space through a stylized repetition of acts" (Butler, 1999: 179). Sehingga karena gender merupakan repetisi dari suatu tindakan, maka mungkin saja secara jenis kelamin seseorang adalah perempuan namun secara gender dia adalah maskulin, karena apa yang dia tunjukkan merupakan tindakan yang maskulin. Disinilah muncul gender trouble, ketika seseorang melakukan hal yang secara normative berlawanan dengan aturan sistem sosial yang berlaku.

Bagaimana cara seseorang mengekspresikan pikirannya, bagaimana cara seseorang untuk mengungkapkan sesuatu, menurut Deborah Tannen dalam genderlact style theory, diantara perempuan dan laki-laki memiliki perbedaan. Tannen mengungkapkan lakilaki cenderung langsung mengatakan sesuatu secara straight to the point, atau yang diistilahkan Tannen sebagai Report Talk. Sedangkan perempuan, cenderung memikirkan keberlangsungan hubungan atau yang diistilahkan Tannen sebagai Rapport Talk (Griffin, 2011: 438-441). Sehingga kemudian muncul gaya komunikasi verbal yang maskulin dan gaya komunikasi verbal yang feminine. Ini karena, seperti dijelaskan diatas, perempuan dalam menggunakan bahasa sangat memperhatikan hubungan yang terjalin dengan pihak lain, sehingga jika dibandingkan dengan laki-laki, umumnya perempuan akan lebih kooperatif.

$\begin{array}{lrr}\text { Elly Burhaini } & \text { Faizal } & (2008) \\ \text { artikelnya } & \text { yang } & \text { dimuat }\end{array}$


langitperempuan.com, memaparkan bahwa dalam media lama/ old media, sebenarnya perempuan telah berusaha untuk menyiratkan idealisme yang dimilikinya. Salah satunya dengan munculnya media perempuan, suatu pengistilahan yang menggambarkan suaru media yang muatannya dari dan untuk perempuan. Misalnya majalah perempuan, Femina, Kartini, Cosmopolitan. Tak cuma mengekspresikan gaya hidup, majalahmajalah itu memang telah mencetak para penulis wanita. Disadari atau tidak, mereka mencoba merebut kekuasaan sekaligus menolak untuk dikuasai. Namun sayang, apa yang dilakukan berbagai media perempuan ini bersimpang jalan dengan apa yang disebut "tuntutan pasar". Mereka mencetak perempuan bebas dan mandiri, tetapi sekaligus menjadikannya sebagai makhluk yang lemah. Alih-alih makhluk berakal, berprestasi, perempuan lebih banyak ditampilkan sex appeal-nya.

Artikel Luisita Lopez Torregroza (2010) yang dimuat dalam politicsdaily.com menjelaskan walau memang perempuan telah banyak memanfaatkan media online, tapi masih ada yang menembunyikan identitasnya agar suaranya lebih didengar. Torregroza menambahkan bahwa perempuan dalam new media banyak yang lebih aktif dan sukses menulis, mengungkapkan pemikirannya. Namun demikian ditambahkan juga, tetap saja di media online ini perempuan masih ada yang menyembunyikan identitasnya.

\section{Pembahasan \\ GAYA BAHASA PEREMPUAN DALAM MEDIA BARU}

Gaya bahasa laki-laki dan perempuan berdasar pendapat dari Deborah Tannen, memiliki perbedaan yang mendasar (Tannen, 2003: 27). Lebih lanjut Tannen menjelaskan bahwa laki-laki dalam menggunakan bahasanya, cenderung menunjukkan sisi yang independen, atau dengan kata lain dia fokus pada penunjukkan pemikiran individu dirinya, sedang perempuan lebih terfokus pada hubungan atau kedekatannya dengan orang lain (intimacy), sehingga dalam menggunakan bahasanya memperhitungkan juga penerimaan orang lain. Deborah Tennen menyebut gaya bahasa laki-laki dengan Report Talk dan gaya bahasa perempuan dengan Rapport Talk (Griffin, 2011: 438-441). Report Talk menunjukkan gaya bahasa laki-laki yang cenderung langsung mengatakan sesuatu secara straight to the point, apa yang ada diungkapkan apa adanya. Rapport Talk menunjuk pada gaya bahasa perempuan yang dalam mengungkapkan sesuatu mengolahnya terlebih dahulu agar penerimaan orang lain atas sesuatu yang dia katakan menjadi lebih baik.

Berdasarkan pengamatan pada media sosial, yang merupakan bagian dari media baru, gaya bahasa perempuan yang muncul terkelompook dalam 2 jenis, yaitu gaya bahasa maskulin dan gaya bahasa feminim. Dimana masing -masing kelompok gaya bahasa tersebut memiliki variannya masing-masing.

\section{Gaya Bahasa Feminim}

Gaya Bahasa Feminim merupakan gaya bahasa perempuan dimana gaya bahasa yang ditampilkannya mengadopsi gaya bahasa perempuan. Gaya bahasa perempuan cenderung berorientasi pada terjalinnya suatu hubungan. Hal ini sejalan dengan istilah Rapport Talk yang dikemukakan Deborah Tannen untuk menggambarkan gaya bahasa perempuan (Tannen, 2003: 25-48). Berdasarkan hasil pengamatan penulis, ditemukan berbagai gaya bahasa feminim perempuan. Berdasar kombinasi kata yang digunakan, susunan kalimat, dan tanda baca yang 
dipakai, maka gaya bahasa feminim dibagi menjadi :

\section{a. Gaya Bahasa "Lemah"}

Kata lemah menggambarkan kondisi yang tidak berdaya, yang mendapat tekanan dari pihak mayoritas atau yang lebih dominan (Bartens, 2009: 36). Tannen mengungungkapkan, bahwa perempuan memiliki gaya bahasa yang diarahkan untuk menciptakan dan mempererat suatu hubungan, atau yang diistilahkan dengan Rapport Talk (Griffin, 2011: 438-441). Dikatakan pula bahwa dalam menjalani percakapan, perempuan menganggap keluh kesah merupakan bagian dari Rapport Talk, dengan keluh kesah perempuan akan mengundang orang untuk bersimpati. Hal ini mendorong peningkatan keintiman dalam hubungan, sebab pada dasarnya perempuan suka dilindungi, sehingga tak jarang posisi lemah, sub ordinat, powerless yang mungkin muncul bukan dianggap sebagai masalah.

Gaya bahasa lemah merupakan gaya bahasa perempuan dalam Facebook dimana gaya bahasa yang digunakan cenderung menunjukkan dirinya sebagai perempuan dalam identitas dirinya yang lemah. Dalam hal ini, dikatakan gaya bahasa lemah jika mengindikasikan subordinat, mengandung keluhan baik dari dalam diri maupun dari luar.

\section{b. Gaya Bahasa "Ekspos"}

Griffin menjelaskan, perempuan berusaha terus melibatkan rekan bicaranya untuk menjaga jalinan hubungan. Perempuan cenderung suka menceritakan kehidupannya, menggambarkan pemikirannya dalam perbincangan pribadinya dengan rekannya (Griffin, 2011: 438-441). Berkeluh kesah, mencurahkan perasaan dalam hati pada lawan bicara merupakan hal yang bisa diterima sebagai bagian dari rapport talk. Menceritakan hidup merupakan hal yang wajar dilakukan perempuan. (Tannen, 2003: 114-117).

Gaya bahasa ekspos merupakan gaya bahasa perempuan yang cenderung suka menceritakan hal-hal yang terjadi dalam hidupnya dan apa yang sedang dirasakannya hingga ke hal-hal kecil pun diceritakannya. Namun berbeda dengan gaya bahasa lemah yang telah dijelaskan sebelumnya, gaya bahasa ekspos ini dalam kalimat yang digunakannya tidak mengandung keluhan, penulis pesan hanya menceritakan hidupnya dan seolah ingin mengajak pembaca pesannya untuk mengenal kehidupannya lebih dekat. Pengamatan menunjukkan, gaya bahasa ekspos perempuan dalam media sosial dibagi menjadi tiga, yaitu, gaya bahasa ekspos keluarga, gaya bahasa ekspos pekerjaan, gaya bahasa ekspos aktivitas.

Pada gaya bahasa ekspose keluarga, penulis pesan dalam menyampaikan gaya bahasa yang diungkapkannya memperlihatkan bahwa suka menceritakan hal-hal terkait dengan keluarganya. Apa yang dirasakannya, apa yang dialaminya, dan hal-hal lain yang menyangkut keluarga terutama anak, diceritakannya, hingga ke hal-hal kecil yang terjadi.

Pada gaya bahasa ekspose aktivitas, penulis pesan dalam menyampaikan gaya bahasa yang diungkapkannya memperlihatkan bahwa dirinya suka menceritakan hal-hal terkait dengan aktivitasnya. Apa yang dilakukannya, hingga ke hal-hal yang sebenarnya biasa juga diungkapkannya, dibagi untuk diketahui pembacanya. 
Pada gaya bahasa ekspose pekerjaan, penulis pesan dalam menyampaikan gaya bahasa yang diungkapkannya memperlihatkan bahwa suka menceritakan pekerjaannya serta hal-hal lain yang terkait dengan pekerjaannya. Apa yang diceritakannya menunjukkan apa yang sedang dilakukannya, kegiatan apa terkait pekerjaan yang sedang dijalaninya, serta suatu pencapaian yang telah didapatnya terkait pekerjaan yang dilakukan.

\section{c. Gaya Bahasa "Sabar Dan Tegas"}

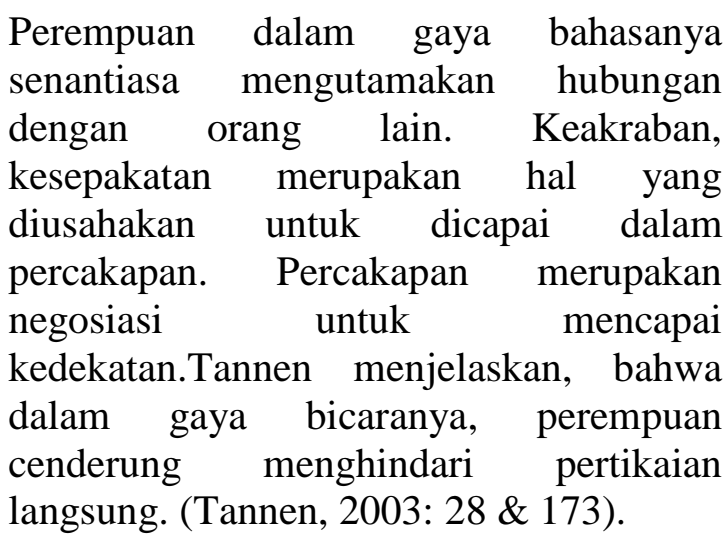

Gaya bahasa sabar dan tegas, merupakan gaya bahasa perempuan yang menggambarkan dirinya tegas dalam menghadapi satu hal namun tetap mengerti kesulitan orang lain, memiliki kesabaran dan bijaksana dalam menghadapi suatu hal, serta menghindari konfrontasi langsung dengan orang lain. Gaya bahasa yang bisa dikelompokkan sebagai gaya bahasa sabar dan tegas, merupakan gaya bahasa yang menunjukkan kesabaran dalam menghadapi sesuatu, sehingga yang diungkapkannya memperlihatkan bahwa dirinya merupakan pribadi yang sabar dalam menghadapi hal yang sebenarnya kurang berkenan baginya; tegas dalam menyampaikan satu hal, namun tidak mengundang konfrontasi secara langsung, sehingga hubungan baik tetap terjaga

Gaya Bahasa Maskulin
Gaya Bahasa Maskulin merupakan gaya bahasa perempuan dimana gaya bahasa yang ditampilkannya mengadopsi gaya bahasa laki-laki. Gaya bahasa laki-laki cenderung berorientasi pada status yang dimilikinya, berjuang untuk memenangkan suatu kompetisi dalam percakapan. Hal ini sejalan dengan istilah Report Talk yang dikemukakan Deborah Tannen untuk menggambarkan gaya bahasa laki-laki. Menurut Tannen, lakilaki memandang status dalam hubungan percakapan merupakan bagian yang penting, sehingga laki laki tidak takut beradu argument secara tegas untuk mempertahankan pendapatnya (Tannen, 2003: 25-48).

Berdasarkan pengamatan penulis, ditemukan berbagai gaya bahasa maskulin dari perempuan. Berdasar kombinasi kata yang digunakan, susunan kalimat, dan tanda baca yang dipakai, maka gaya bahasa maskulin dibagi menjadi :

\section{a. Gaya Bahasa "Cerdas"}

Tannen mengungkapkan, untuk mencapai status yang diharapkan, laki-laki melakukannya dengan memamerkan pengetahuan dan kecakapan atau berbagi informasi. Laki-laki cenderung nyaman jika dianggap sebagai pihak pemberi informasi, pihak memiliki banyak ilmu dan kecakapan, pihak yang cerdas diantara komunitasnya. (Tannen, 2003: 70-78 \& 87). Sehingga perempuan yang menggunakan gaya bahasa demikian, dianggap memiliki gaya bahasa yang maskulin.

Kata cerdas menunjukkan kemampuan menawarkan cara pandang perbeda, perspektif berbeda dalam melihat dunia dan memaknai nilai dalam kehidupan (Sarbana, 2009 : xii). Identitas cerdas, merupakan identitas perempuan dalam 
facebook yang dari gaya bahasanya berani menunjukkan bahwa dirinya adalah memiliki pemikiran yang kritis dan tajam serta pengetahuan luas. Perempuan dengan gaya bahasa cerdas tidak risih menunjukkan dirinya yang berpengetahuan luas dengan pemikiran kritis dan tajam. Dalam menunjukkan daya kritisnya ada yang menggunakan gaya satir tanpa menyebut pihak yang disindir secara langsung, dan ada yang langsung menyebut pihak yang dikritisi secara jelas. Penulis pesan dalam gaya bahasa yang digunakan selain menunjukkan daya pikirnya yang kritis dan tajam, dilakukan dengan pilihan kata yang tidak kasar. Sehingga keseluruhan kata dalam kalimat yang digunakan masih bisa diterima norma masyarakat secara umum. Kemampuan memilih kata yang tepat dan baik dalam menyampaikan apa yang dimaksudkan, secara tak langsung menunjukkan tingkat kecerdasan penggunanya. Namun demikian mereka yang menggunakan gaya bahasa cerdas ini tidak takut memancing konfrontasi langsung jika memang dibutuhkan, hanya saja tidak dilakukan dengan cara yang terkesan keras.

\section{b. Gaya Bahasa "Keras"}

Menurut Tannen, percakapan bagi lakilaki merupakan ajang pertarungan status unuk menunjukkan siapa yang memiliki status yang lebih unggul diantara semua peserta percakapan, sehingga terkadang kata-kata yang kasar bukanlah sesuatu yang tabu digunakan. Dalam percakapanpun, laki-laki tidak menghindari perdebatan atau pertikaian terbuka, justru hal ini makin menguatkan pertarungan status yang ada. (Tannen, 2003: 28 \& 173).

\section{DAFTAR PUSTAKA}

Gaya bahasa "Keras" disini tidak kemudian diartikan sebagai sesuatu yang negatif. Gaya bahasa "Keras" merupakan gaya bahasa perempuan dalam media sosial yang secara keras dan jelas menunjukkan apa yang dimaksudnya, bukan hanya secara langsung menunjukkan pendapatnya, tapi juga tidak segan menggunakan kata-kata yang keras dalam kalimat yang digunakan.

Gaya bahasa keras disini, ditunjukkan dengan ciri berani menunjukkan pendapat secara langsung, tidak menghindari menggunakan kata yang kasar, sehingga kalimat yang muncul terkesan keras serta tidak takut memancing konfrontasi langsung.

\section{Kesimpulan}

Pada media baru, dalam hal ini media sosial sebagai bagian dari media baru, masih terjadi kondisi identitas mute/ terbisukan dalam media sosial bagi sebagian perempuan. Gaya bahasa yang digunakan dalam status pun cenderung menunjukkan gaya bahasa khas feminim, yang cenderung mengutamakan hubungan, menghindari perselisihan, dan meminimalisir kesan dominan. Berdasarkan pengamatan, hanya sedikit perempuan Indonesia yang terpantau penulis yang berani menunjukkan pendapatnya secara langsung dan frontal, dengan kata lain menunjukkan gaya bahasa keras. Gender trouble terjadi pada sebagian perempuan. Penggunaan gaya bahasa maskulin menyebabkan identifikasi karakteristik gender jadi semakin bias, karena identitas yang ditampilkan tidak sesuai dengan norma kultural yang berjalan.

Adler, Ronald B \& George Rodman. 2006. Understanding Human Communication ( $8^{\text {th }}$ edition), New York: Oxford University Press. 
Bartens, K. 2009. Perspektif Etika Baru. Yogyakarta: Kanisius.

Butler, Judith. 1999. Gender Trouble. London: Rautledge.

Fiske, John, 2007. Cultural and Communication Studies, Yogyakarta \& Bandung : Jalasutra.

Flew, Terry. 2002. New Media: An Introduction. UK: Oxford University Press.

Griffin, E.M. 2011. A First Look At Communication Theory. Eight Edition. New York: McGraw Hill. langitperempuan.com/2008/06/perempuan -dalam-media-perempuan/ (diakses tanggal 5 April 2011, pukul 19.00 WIB)

Luik, Jandi.E, 2011. Media Sosial dan Presentasi Diri. dalam Fajar

Sobur, Alex. 2006. Semiotika Komunikasi, Bandung: CV.Remaja Rosdakarya.

Tannen, Deborah, 2003. Kamu Memang Nggak Bakal Ngerti: Romantika Percakapan Wanita dan Pria, Bandung: Qanita.
Junaedi (ed). Komunikasi 2.0:

Teoritisasi dan Implikasi.

ASPIKOM, Yogyakarta. pp.108129

Mcquail, Dennis. 2010. McQuail's Mass Communication Theory. UK : Sage Publications, Ltd.

Palfrey John \& Urs Gasser, 2008. Understanding The First Generation of Digital Natives. New York: Basic Books.

politicsdaily.com/2010/04/19/women-innew-media-at-the-top-or-in-thetrenches/ (diakses tanggal 5 April 2011, pukul 20.30 WIB)

Sarbana, Baban. 2009. Hati Tak Bersudut: Setelah Kesussahan ada Kemudahan. Jakarta: Elex Media Komputindo.

Utari, Prahastiwi, 2011. Media Sosial, New Media dan Gender Dalam Pusaran Teori Komunikasi. dalam Fajar Junaedi (ed). Komunikasi 2.0: Teoritisasi dan Implikasi.ASPIKOM, Yogyakarta. pp.49-60. 
